DOI: https://doi.org/10.32839/2304-5809/2021-5-93-2

УДК 656.61.052(075.8)

Леонов В.Е. ${ }^{1}$

Херсонская государственная морская академия; действительный член Международной академии «Экоэнергетика»

Харченко В.C.

Херсонская государственная морская академия

\title{
ИССЛЕДОВАНИЕ ПРИЧИН И ПУТЕЙ РЕШЕНИЯ «КЛИМАТИЧЕСКОГО» КРИЗИСА
}

Аннотация. В научной работе приведены научно-технические публикации по прогрессирующим изменениям климата на планете, обусловленные повышением среднегодовой температуры атмосферного воздуха, морского океанической среды и как следствие сопровождается нарушением, а в отдельных случаях разрушением природных әкосистем, биотических группировок, биом. Возможная причина изменения климата на планете - «парниковый» әффрект. Мнения ученых и экспертов по вопросу «парникового» эффекта на планете и его последствий разделились на диаметрально-противоположные: 1) имеется «парниковый» эдффект; 2) нет "парникового» әфрфекта. И это противоречие на наш взгляд вполне понятно. Действительно провести исследования в глобальном масштабе в трех экологических нишах окружающей среды невозможно. Поэтому исследователями предлагаются различные модели, адекватность которых проверить в глобальном масштабе окружающей среды, космоса невозможно. Несмотря на противоречивость взглядов на «парниковый» эффект, можно констатировать, что последствия повышения среднегодовой температуры воздушного бассейна, морского океанической среды весьма негативные и прогнозируемые катастрофически. Нами проведен анализ и расчетные исследования в течение последних 60-ти лет, характеризующихся наиболее интенсивным потреблением углеводородного сырья невозобновимого характера, по накоплению диоксида углерода-маркера «парникового» эффекта - в трех нишах окружающей среды. Из результатов проведенных исследований следует вывод о конгруэнтности рост эмиссии диоксида углерода антропогенного характера в воздушном бассейне и повышение среднегодовой температуры воздушного бассейна, можно предположить и повышение среднегодовой температуры морской среды, в зависимости от времени. Приведены примеры реализации научно-исследовательских работ по снижению эмиссии компонентов "парниковых» газов на морском транспорте, что позволит решить двухвекторную задачу - повысить әкономическую эффективность морских грузоперевозок и обеспечить экологическую безопасность морских грузоперевозок.

Ключевые слова: «парниковый» эфррект, техногенные системы, морской транспорт, диоксид углерода, температура, окружающая среда, морская, океаническая среда, экономическая эффрективность, экологическая безопасность, решение проблем, планета, зависимость, компоненты «парниковых» газов, судоходство.

Leonov Valery Kherson State Maritime Academy; Full member of the International Academy "Ecoenergy"

Kharchenko Vladyslav

Kherson State Maritime Academy

\section{RESEARCH OF THE CAUSES AND WAYS OF SOLVING THE"CLIMATE" CRISIS}

Summary. The article presents scientific and technical publications on the progressive climate change on the planet, caused by an increase in the average annual temperature of atmospheric air, marine oceanic environment and, as a consequence, accompanied by the disruption, and in some cases destruction of natural ecosystems, biotic communities, biomes. A possible cause of climate change on the planet is the "greenhouse" effect. The opinions of scientists and experts on the issue of the "greenhouse" effect on the planet and its consequences were divided into diametrically opposed ones: 1) there is a "greenhouse" effect; 2) there is no "greenhouse" effect. And this contradiction, in our opinion, is quite understandable. Indeed, it is impossible to conduct research on a global scale in the three ecological niches of the environment. Therefore, researchers offer various models, the adequacy of which is impossible to verify on a global scale of the environment, space. Despite the contradictory views on the "greenhouse" effect, it can be stated that the consequences of an increase in the average annual temperature of the air basin and the marine oceanic environment are very negative and predictably catastrophic. We have carried out an analysis and computational studies over the past 60 years, characterized by the most intensive consumption of hydrocarbon raw materials of a non-renewable nature, by the accumulation of carbon dioxide, a marker of the "greenhouse" effect, in three environmental niches. From the results of the studies carried out, a conclusion suggests itself about the congruence of the growth of anthropogenic carbon dioxide emissions in the air basin and the increase in the average annual temperature of the air basin, it is possible to assume an increase in the average annual temperature of the marine environment, depending on time. How to get out of this situation of irreversible nature - there are ways, it is more difficult to make a decision on a planetary scale. The examples of the implementation of research work to reduce the emission of components of "greenhouse" gases in marine transport, which will solve the two-vector task - to increase the economic efficiency of sea freight and ensure the environmental safety of sea freight.

Keywords: "greenhouse" effect, man-made systems, marine transport, carbon dioxide, temperature, environment, marine, oceanic environment, economic efficiency, environmental safety, problem solving, planet, dependence, components of "greenhouse" gases, shipping.

${ }^{1}$ ORCID: https://orcid.org/0000-0001-5590-8807 
Введение. 23 апреля 2021 г. по инициативе США был проведен международный саммит по "климату", приглашены 40 ведущих стран мира. По данным «Global Carbon Atlas» мировыми лидерами по эмиссии диоксида углерода-основного компонента "парниковых" газов являются Китай, США, Индия, Россия, Япония, Иран, Германия, Индонезия, Ю. Корея. В выступлениях лидеров ведущих стран мира сообщено, что к 2050 году эмиссия диоксида углерода снизится в 3-5 раз.

Техногенные системы, в частности морской транспорт, являются основными «поставщиками» компонентов «парниковых» газов, к которым относятся такие вещества и соединения как диоксид углерода, углеводороды, закись азота, органическая минеральная пыль, сажа, пары воды.

Мнения ученых и экспертов по вопросу планетарного «парникового» эфрфекта диаметрально противоположны. И это, на наш взгляд, под собой имеет основу. Действительно, чтобы ответить на простой вопрос, есть ли «парниковый» эфрфект на планете или его нет, необходимо иметь достоверные материалы, полученные в результате научно-исследовательских работ. Провести же эксперименты в глобальном масштабе планеты и космоса в направлении изучения «парникового» эфрфекта на современном этапе не представляется возможным. Поэтому работа проводится по предложенным гипотетическим моделям. В расчетных исследованиях используются методы математического моделирования, на основании которых избирательно делаются выводы о наличии или неналичии «парникового» эфрфекта на Земле. Недостаток любых предложенных моделей «парникового» эфрфекта - это отсутствие и/или невозможность проверки их на адекватность в реальных условиях эксперимента на планете и в космосе.

Анализ публикаций по сути рассматриваемого вопроса. Идея о механизме «парникового» эффректа была впервые изложена в 1827 году Жозедом Фурье в статье «Записка о температурах земного шара и других планет», в которой он рассматривал различные механизмы формирования климата Земли, при этом он рассматривал как фракторы, влияющие на общий тепловой баланс Земли, (нагрев солнечным излучением, охлаждение за счет лучеиспускания, внутреннее тепло Земли), так и фракторы, влияющие на теплоперенос и температуры климатических поясов (теплопроводность, атмосдерная и океаническая циркуляция).

В работах $[1 ; 2]$ приведен подробный анализ возможных причин возникновения и последствий «парникового» эфрдекта.

Ученые из Калифорнийского университета в Ирвине (США) сообщили об угрозе потопа для 400 млн. человек из-за потепления, «парникового» эфрфекта [3]. Таяние ледников Гренландии значительно подняло уровень Мирового океана за два месяца он увеличился на 2,2 мм. Причиной тому стало таяние более 600 млрд. тонн льда. Эти процессы сопровождало слишком теплое лето 2019 года и этот период был самым теплым за всю историю Арктики. Расчетами было показано, что лед в Гренландии стал таять в семь раз быстрее, чем это было в 1990-х годах.

Содержание диоксида углерода в атмосфрере Земли в августе 2019 года увеличилось на три пункта относительно аналогичного показателя 2018 года, а это значит, что человечество не может сократить выбросы $\mathrm{CO}_{2}$ в атмосферу и затормозить глобальное потепление, заявили в Национальном управлении по аэронавтике и космосу (HАСА, США) [4].

Спещиалисты НАCA подтвердили точность недавно полученных данных по температуре воздушного слоя у поверхности моря, суши, и ледяного покрова с помощью спутника Aqua, свидетельствующих о быстром глобальном потеплении (информация приведена в пресс-релизе на Eurek Alert). Согласно модельным расчетам ученых, если не будет предпринято никаких мер к снижению выбросов "парниковых» газов, то к концу XX1 века температура морской воды в верхнем слое толщиной в 2000 м повысится на $0,78^{\circ} \mathrm{C}$. Это повысит уровень мирового океана только за счет теплового объемного расширения на дополнительные 30 см вдобавок к подъему уровня морской акватории береговой линии изза таяния ледников. Повышение температуры морской среды и воздушного бассейна спровоцирует более сильные штормы, ураганы и экстремальные осадки.

Ученые Торонтского университета (Канада) выяснили, что потепление климата в регионе Юкон на северо-западе Канады стало самым сильным за более, чем десять тысяч лет (инфрормация приведена в пресс-релизе на Eurek Alert). Исследователи считают, что потепление климата на Земле может дестабилизировать вечную мерзлоту, что приведет к еще большим выбросам метана и диоксида углерода - основных компонентов «парниковых" газов.

В работе [5] ученые предлагают распылять в атмосферу воздушного бассейна аэрозоли так, чтобы уменьшить потепление на $50 \%$. Идея сама по себе не нова, но ее подвергали критике. Исследователи создали модель геоинженерии направленного воздействия на климат Земли с распылением в стратосфрере аэрозолей. В модели ученых в качестве аэрозоля рассматривался диоксид серы. Отмечено, что эта мера не решит проблему глобального потепления в целом, но может рассматриваться только как часть комплексного подхода.

В качестве комментария авторов настоящей статьи к работам [5-7]:

1) откуда взять в огромных количествах планетарного масштаба диоксид серы в качестве защитного аэрозоля?;

2) диоксид серы в стратосферном слое атмосферы подвергнется окислению активным окислителем озоном до серного ангидрида, а серный ангидрид при взаимодействии с парами воды, содержащимися в атмосферном воздухе, приведет к образованию серной кислоты.

В результате, не решив проблему глобального потепления Земли, данное предложение приведет и к усилению двух других глобальных проблем - разрушению «озонового слоя» планеты и интенсификации «кислотных» дождей.

На транспортный сектор в 2010 году приходилось $22 \%$ мировых выбросов диоксида углерода $[8,9]$, в том числе в 2013 году на сектор судоходства приходилось 2,2\% мирового выброса $\mathrm{CO}_{2}$ по сравнению с 2,7\% выброса $\mathrm{CO}_{2}$ в 2008 году (IMO, 2014). 
В работе [3] приведены материалы по эмиссии диоксида углерода на общественном транспорте: в Сиднее (Австралия) уровень выбросов диоксида углерода в расчете на пассажиро-километр составил, г: 188 для среднего автомобиля, 120 - на автобус, 105 - на проезд в поезде, 171 - на легкорельсовом транспорте. Выбросы $\mathrm{CO}_{2}$ от каждой цепочки были аппроксимированы суммой выбросов по всем этапам поездки.

Итоги - без сокращения техногенных выбросов компонентов "парниковых» газов не обойтись, не решить глобальную проблему потепления климата на планете Земля [10-13].

Постановка задачи. Нами в порядке дискуссии за последние 60 лет проведены анализ, расчетные исследования по накоплению диоксида углерода - основного компонента «парниковых» газов на планете [14]. Этот период времени был принят исходя из того, что именно указанный период времени характеризовался наиболее интенсивным потреблением углеводородного сырья невозобновимого характера (нефть, природный газ, уголь, сланцы) и, соответственно, наибольшей эмиссией диоксида углерода в атмосфpepy, окружающую среду. Результаты исследований представлены на рисунке 1.

Диоксид углерода независимо от природы его образования может аккумулироваться в раковинах, твердых, горных породах с образованием карбонатов, растворяться в морской воде, участвовать в реакциях фотосинтеза, а излишки диоксида углерода накапливаются в атмосфрерном воздухе.

Динамика интенсивного увеличения суммарной концентрации диоксида углерода в окружающей среде (кривая 1, рис. 1) полностью согласуется с интенсивным расходованием углеводородного сырья за аналогичный период времени. Кривая 2 (рис. 1) характеризует динамику роста концентрации диоксида углерода в атмосдрерном воздухе, включающей в себя два источника образования диоксида углерода - антропогенный (преобладающий) и природный (кривая 4, рис. 1). Нами было обнаружено, что кривая 2 (рост концентрации $\mathrm{CO}_{2}$ в атмосорерном воздухе) и кривая 3 (среднегодовой прирост температуры атмосфрерного воздуха за этот же промежуток времени) практически параллельны (конгруэнтны), что свидетельствует о связи накопления $\mathrm{CO}_{2}$ в атмосферном воздухе со среднегодовым приростом температуры атмосферного воздуха. А это, в свою очередь, определяет роль диоксида углерода как основного компонента «парниковых» газов, стимулирующих «парниковый» эффрект, приводящий к потеплению климата на планете Земля.

Интересным, на наш взгляд, является характер изменения природной концентрации $\mathrm{CO}_{2}$ в атмосфрерном воздухе, почему происходит монотонный рост концентрации $\mathrm{CO}_{2}$ за анализируемый промежуток времени. Можно с высокой степенью достоверности предположить, что за указанный промежуток времени в результате действий человека и техногенных систем органическая база для реакции оротосинтеза (лесные массивы, сине-зеленые водоросли) исчерпывается, ингибируется, что приводит к снижению продуктивности реакции фотосинтеза и, как следствие, к уменьшению массы вовлеченного в реакцию фотосинтеза диоксида углерода. Из-

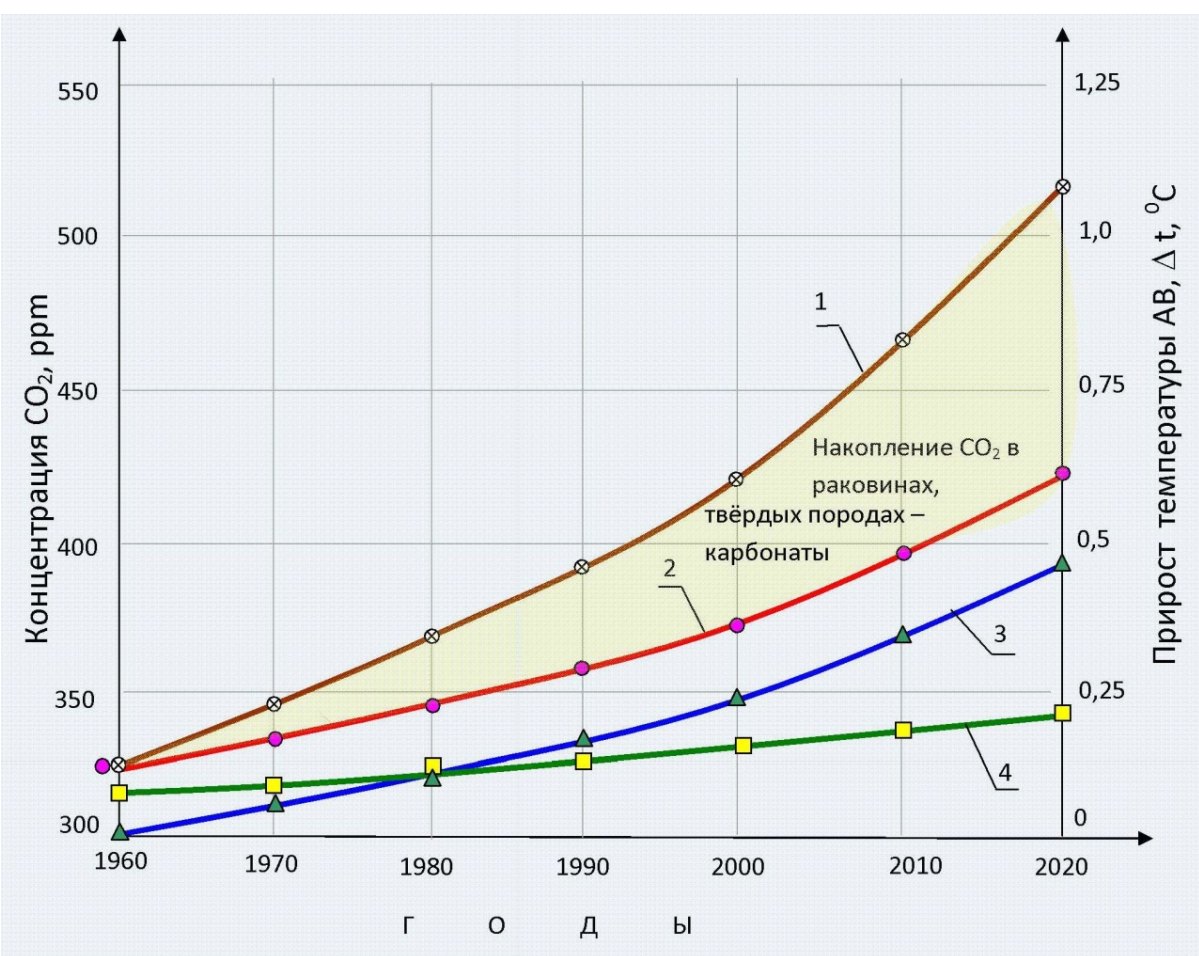

Рис. 1. Изменение концентрации диоксида углерода и среднегодового прироста температуры атмосферного воздуха в зависимости от времени (годы): кривая 1 - общее антропогенное накопление $\mathrm{CO}_{2}$; кривая 2 - антропогенное накопление $\mathrm{CO}_{2}$ в атмосферном воздухе; кривая 3 среднегодовой прирост температуры атмосферного воздуха; кривая 4 - природное накопление $\mathrm{CO}_{2}$ в атмосферном воздухе. Условные обозначения: ppm-part per million (Engl.), одна частица на миллион; $\Delta \mathrm{t}$ - среднегодовой прирост температуры атмосферного воздуха, ${ }^{\circ} \mathrm{C} ; \mathrm{AB}$ - атмосферный воздух 
лишки природного диоксида углерода накапливаются в атмосферном воздухе, что согласуется с ходом зависимости кривой 4 (рис. 1).

Необходимо отметить, что результаты расчетно-аналитических расчетов, проведенных нами, соответствуют данным по накоплению диоксида углерода, полученных японскими исследователями (Главное метеорологическое управление Японии, телеканал NHK) [15]. На основании вышеизложенного о техногенных предпосылках возникновения и интенсификации «парникового» эфрфекта можно предложить «сценарий» влияния изменения климата планеты на окружающую среду, экосистемы, биоту, биомы, биосферу, человека (рис. 2).

В 2015 году в Ле Бурже (Франция) состоялся международный климатический саммит COP-21, который был посвящен проблеме потепления климата на планете и разработке путей преодоления этого кризиса. Более 137 государств мира подписали итоговый Протокол этого саммита. США - наиболее значимый потребитель углеводородного сырья невозобновимого характера и отдельные страны менее значимые в плане потребления углеводородного сырья не подписали итоговый Протокол климатического саммита, освободив себя от финансовых затрат, природоохранных мероприятий. Из этого следует, что большая часть государств мира обеспокоена глобальным потеплением и его последствиями.

В Киотском и Парижском Протоколах по проблеме «парникового» эфрфекта на планете судо- ходство и авиация не были включены в окончательную редакцию Соглашения [2; 13].

Пути решения глобальной проблемы «парникового» эффекта.

В соответствии с проведенным нами анализом морских грузоперевозок и расчетами современный морской транспорт расходует около 1 млрд т в год углеводородного судового топлива, что соответствует эмиссии порядка 3,2 млрд т в год диоксида углерода.

Необходимо отметить, что в 2019 году суммарный выброс диоксида углерода - результат действия техногенных систем - составил 40 млрд тонн. В то же время только от судоходства, включая порты и портовые сооружения, выброс диоксида углерода составил около 4,5 млрд тонн в год.

Таким образом, вклад в целом отрасли техногенной системы - судоходства - в общий «парниковый» эфффект (по диоксиду углерода) составил 11,3\%. Можно допустить, что в авиации примерно такая же величина по вкладу в «парниковый» эфрфект. В итоге на долю судоходства и авиации в общий «парниковый» эфрфект приходится более $22 \%$, а с этим необходимо считаться при прогнозировании развития интенсивности «парникового» эфрфекта на планете.

Исключить эмиссию компонентов «парниковых» газов - диоксида углерода, углеводородов, минеральной пыли, сажи при использовании углеводородного сырья (УС) невозможно.

На основании выполненных нами расчетных исследований можно констатировать, что эмис-

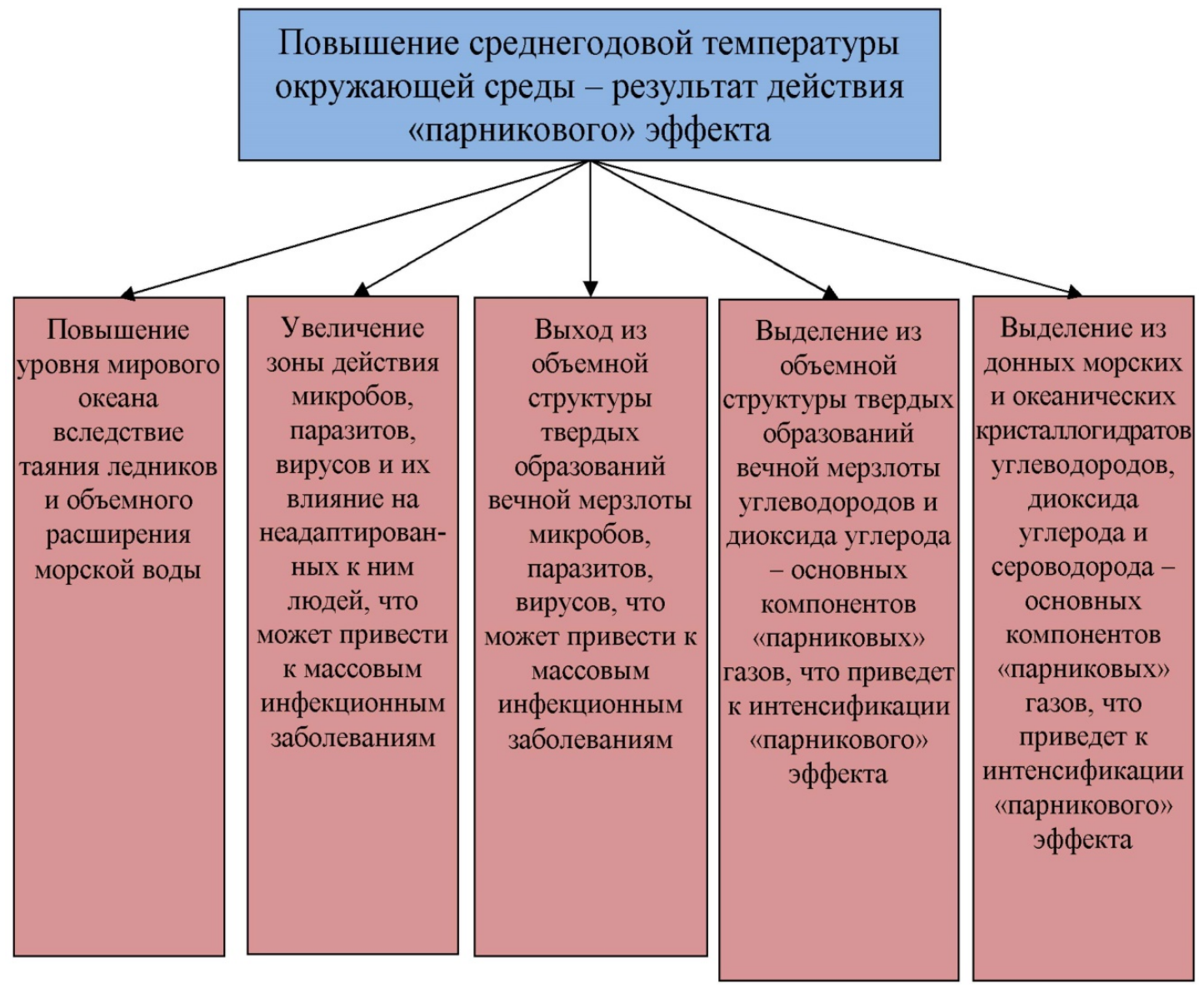

Рис. 2. Влияние повышения среднегодовой температуры окружающей среды на отрицательное воздействие на әкосистемы, биоту, биомы, биосферу, человека 
сия диоксида углерода является следствием переработки углеводородного сырья. Эмиссия диоксида углерода при переработке (сжигании) УС рассчитывалась как общая по уравнению:

$\mathrm{e} \sum \mathrm{CO}_{2}=\mathrm{e}^{\text {доб }} \mathrm{CO}_{2}+\mathrm{e}^{\mathrm{Tp} .} \mathrm{CO}_{2}+\mathrm{e}^{\text {пер. }} \mathrm{CO}_{2}+\mathrm{e}^{\text {сж }} \mathrm{CO}_{2},(1)$

где $\mathrm{e}^{\text {доб }} \mathrm{CO}_{2}, \mathrm{e}^{\text {тр. }} \mathrm{CO}_{2}, \mathrm{e}^{\text {пер. }} \mathrm{CO}_{2}, \mathrm{e}^{\text {сж }} \mathrm{CO}_{2}-$ соответственно, эмиссия диоксида углерода при добыче УC, его транспортировке, переработке и сжигании, г $\mathrm{CO}_{2}-$ экв./кг усл. топл., так и в результате

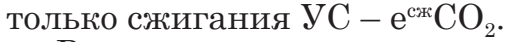

Результаты расчетов приведены на рисунке 3.

Из рисунка 3 следует, что эмиссия диоксида углерода, как общая, так и только в результате сжигания, снижается в ряду «уголь $\rightarrow$ мазут $\rightarrow$ природный газ $\rightarrow$ водород». В качестве окислителя при сжигании УС использовался воздух.

В случае сжигания водорода в потоке кислорода эмиссия диоксида углерода при сжигании равна нулю, а общая эмиссия диоксида углерода равна 833 г $\mathrm{CO}_{2}$ - экв./кг усл. топл. (рис. 3).

Ресурсосберегающие технологии позволяют, с одной стороны, снизить удельный расход углеводородного сырья (УС) на условную тонну целевой продукции, а с другой - снизить выбросы материальных и уровень энергетических отходов техногенных систем.

Ниже приведены технические предложения, которые позволят снизить эмиссию диоксида углерода и, соответственно, снизить действие «парникового» эфрфекта:

1. Разработка и реализация малоотходных, ресурсосберегающих технологий, позволяющих снизить образование материальных отходов и, как следствие, снизить выбросы диоксида углерода.

2. Извлечение, концентрирование, сбор, перевод в жидкое агрегатное состояние, хранение и транспортировку сжиженного диоксида углерода.

3. Химическая переработка диоксида углерода методом каталитического гидрирования в метанол [16] и на основе метанола производство пластических масс, карбамидо-фрормальдегидных смол, карбоновых кислот, удобрений, фрармацевтической продукции, высокооктановых компонентов моторного топлива, водорода, этилена, белкововитаминного концентрата, ингиби- тора гидратообразования при добыче углеводородных газов.

В Херсонской государственной морской академии (научный руководитель профрессор Леонов В.Е.) проводятся научно-исследовательские, опытные и опытно-промышленные работы по разработке ресурсосберегающих, экологически безопасных технологий и использованию неуглеводородного сырья (НУС) для обеспечения функционирования техногенных систем.

Бассейн Черного моря является мощным источником нетрадиционных энергоресурсов, а именно: сероводород и донные кристаллогидраты. Донные кристаллогидраты представляют собой твердофазный сплав льда и растворенных (адсорбированных) углеводородов $\mathrm{C}_{1}-\mathrm{C}_{5+}$. Texническая проблема в использовании кристаллогидратов состоит в их добыче, транспортировке на поверхность морской среды, а регазификация и переработка кристаллогидратов в химические соединения и моторное топливо не представляют промышленных осложнений и могут быть реализованы в существующих нефтехимических комплексах.

Сероводород, содержащийся в бассейне Черного моря, представляет огромную потенщиальную опасность для стран Причерноморья $[1 ; 2 ; 13]$.

Научно-технические проблемы широкого использования сероводорода для производства моторных топлив и химических соединений включают следующие стадии [2; 13]:

- глубоководная добыча сероводорода;

- эрффективная переработка сероводорода в моторное топливо и химические соединения, электроэнергию.

Нами разработано оригинальное техническое решение по глубоководной морской добыче сероводорода $(\approx 10000$ м), решение защищено патентом Украины [17].

Техническим решением [17] предусмотрена стационарная морская платформа, на которой осуществляется сбор, хранение и подготовка добытого сероводорода к последующей комплексной переработке. Последняя осуществляется также на морской платформе.

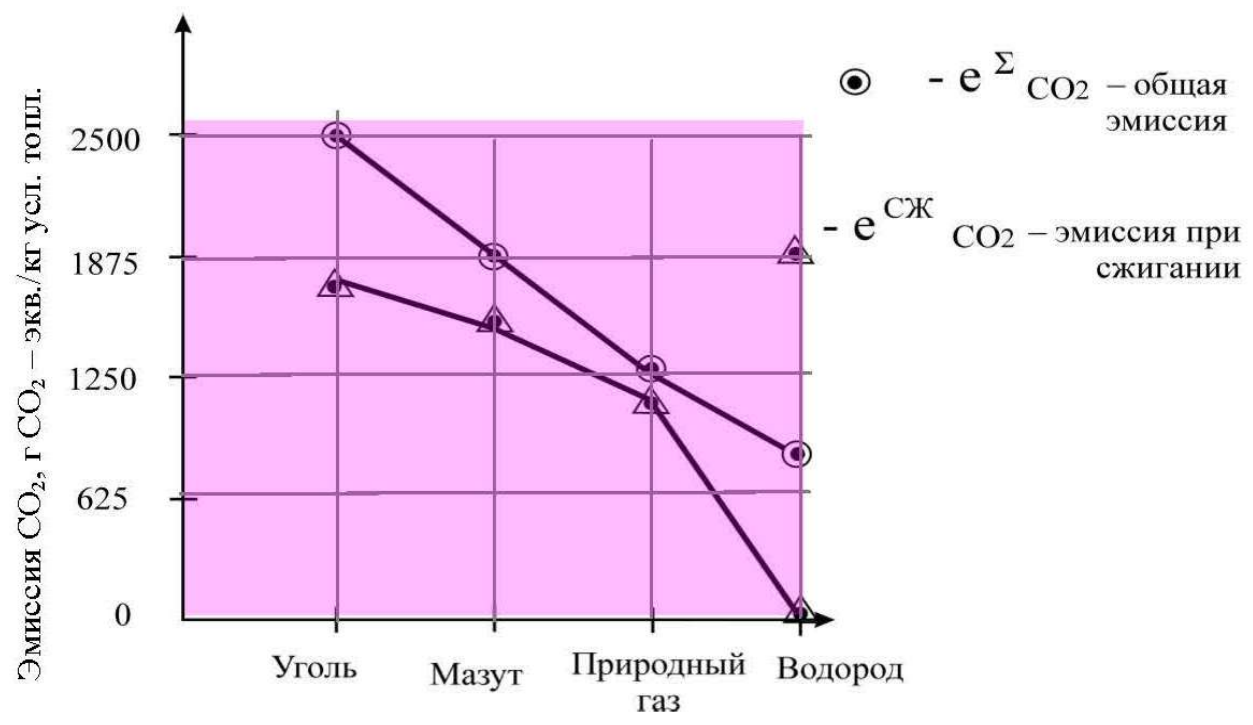

Рис. 3. Эмиссия диоксида углерода в зависимости от вида сжигаемого топлива 
Предложены способы переработки сероводорода, серосодержащих соединений в ценные химические соединения и тепловую энергию. Способы отличаются высокими технико-экономическими показателями, эмиссия вредных токсичных компонентов с отработанными газами СЭУ в атмосфреру полностью отсутствует.

При комплексной добыче и переработке сероводорода Черного моря решаются основные проблемы экологической безопасности, экономической целесообразности, ресурсосбережения, защиты морской окружающей среды:

1) снижается потенциальная опасность «прорыва» через толщу морской воды токсичного, взрывопожароопасного сероводорода;

2) снижается зависимость стран от импорта углеводородных энергоносителей;

3) резко снижается социально-экономический и экологический ущерб окружающей среде стран Причерноморья.

Исходя из реального положения дел с запасами УС, времени их исчерпания, можно предложить три сценария перехода с УС на НУС:

1) оставшееся время действия и эксплуатации УС для обеспечения техногенных систем, отвечающим требованиям ресурсосбережения;

2) переходной период, когда доля НУС в общем энергетическом балансе будет составлять $50 \%$ и более, вплоть до полного замещения УС на $100 \%$ НУС;

3) установившийся период реализации неуглеводородного сырья для фрункционирования техногенных систем.

Завершающаяся эпоха углеводородного сырья характеризуется существенным «сдвигом» цивилизации в сторону неустойчивого развития общества $[1 ; 2]$. Эта неустойчивость характеризуется существенным влиянием «парникового» эфрфекта, разрушением озонового слоя планеты и экосистем, интенсивным исчерпыванием невозобновимых и возобновимых источников энергии, кислорода, природной пресной воды.

В качестве рекомендаций можно предложить следующие основные направления деятельности в рамках первой стадии - УС:

1) «законсервировать» дальнейшую разведку, разработку и добычу углеводородного сырья, оставить оставшееся УС будущим поколениям в качестве резерва;

2) перевести техногенные системы на ресурсосберегающие, экологически безопасные технологии [2;13];

3) снизить техногенное влияние на развитие «парникового» эфрфекта.

При добыче, хранении, транспортировке недрт, а также при ее переработке в бензин, дизельное, котельное топливо, мазут, помимо случайных и аварийных потерь, имеют место систематические потери углеводородов (УВ), обусловленные испарением жидких УВ с поверхности при "больших" и “малых" дыханиях в емкостной аппаратуре. «Большие» дыхания это выделение воздуха с парами углеводородов из резервуаров при закачке в последние нефти и светлых недртепродуктов, «малые» дыхания резервуаров обусловлены разностью температур воздуха днем и ночью. Общие потери углеводо- родов в мире достигают десятки миллионов тонн в год. При этом наносится прямой экономический ущерб за счет потерь нефти и нефтепродуктов и эколого-экономический ущерб вследствие загрязнения воздушного бассейна углеводородами - компонентами «парниковых» газов.

Потери УВ только при заправках и хранении нефрти и нефтепродуктов составляют 1100 г УВ/м ${ }^{3}$ воздушно-углеводородной смеси. Согласно действующим директивам Европейского союза концентрация УВ в парообразном состоянии не должна превышать 35 г УВ/м ${ }^{3}$, то есть потери УВ необходимо снизить более чем в 30 раз по требованиям Евросоюза $[1 ; 2 ; 13]$.

Для снижения эмиссии углеводородов в атмосферу в процессе эксплуатации танкеров, газовозов, химогазовозов, метановозов разработаны к практической реализации на морском транспорте инновационные технические решения [2; 13].

При выделении углеводородов в атмосdpepный бассейн наносится экономический ущерб и эколого-экономический ущерб.

Разработаны три варианта технологии поглощения углеводородов из газовоздушных сред при «больших" и «малых" дыханиях резервуаров. Выбор той или иной технологии зависит от объемов поставляемой нефти и светлых нефтепродуктов, конструктивных особенностей и аппаратурного офрормления конкретного объекта. Технологии отработаны в опытно-промышленных условиях. Разработана технология поглощения УВ адсорбционным методом (рис. 4).

Технология включает следующие основные стадии:

1. Сбор и компримирование воздушно-углеводородной смеси, выходящей из хранилища поз. 2.

2. Адсорбция паров УВ в адсорбере поз. 7 .

3. Регенерация насыщенного адсорбента в адсорбере поз. 17 в потоке инертного газа при повышенной температуре.

4. Охлаждение паров УВ в холодильнике-конденсаторе поз. 18.

5. Разделение инертного газа и жидких УВ в сепараторе поз. 22.

6. Возврат инертного газа после сепаратора поз. 22 в цикл регенерации.

7. Возврат бензина (жидких углеводородов) в хранилище поз. 2.

Характеристика процесса заправки

При вытеснении 1 м $^{3}$ воздуха теряется 1 кг паров бензина. Примем объем хранилища $1000 \mathrm{~m}^{3}$, тогда потери бензина при одной заправке-выдаче составят:

$1 \kappa \Gamma \cdot 1000 \cdot 2=2000 \kappa \Gamma=2$ т бензина.

При 100 заправках-выдачах потери бензина составят: $1,19 \times 200000 / 0,743=320323$ USD,

где 0,743 - плотность бензина, кг/л;

1,19 - стоимость 1 л бензина АИ-95, USD.

Экономическая эффрективность от реализации установки по улавливанию паров бензина при степени поглощения 95\% составляет: $320323 \times 0,95=304307$ USD.

Технология процесса улавливания паров УВ защищена патентами [2; 13$]$.

Выводы. Таким образом, в результате выполненной работы можно сделать следующие выводы: 


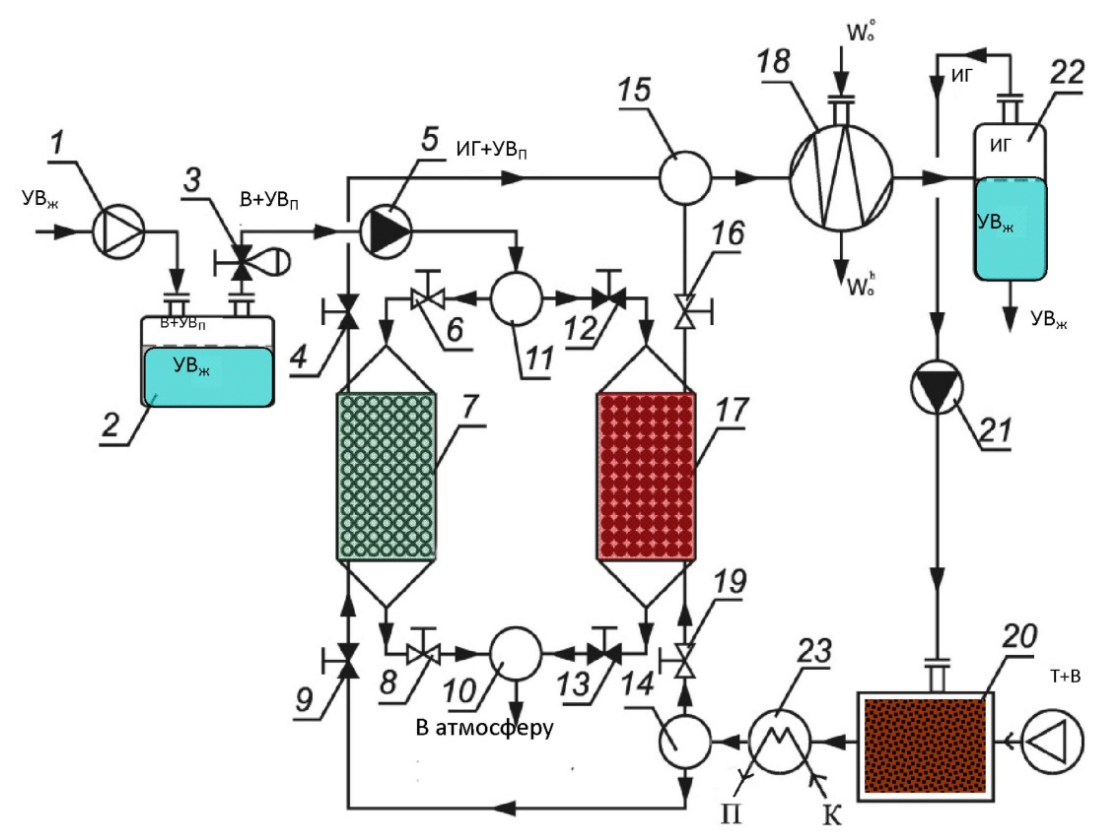

Рис. 4. Принципиальная схема улавливания паров углеводородов [2; 13]

1. Потери УВ при транспортировке и хранении недтепродуктов имеют два отрицательных вектора - экономический и экологический.

2. Проведены исследования по поглощению паров углеводородов в статических и динамических условиях.
3. Разработаны ресурсосберегающие технологии поглощения УВ из паровоздушных сред.

4. Проведены опытно-промышленные испытания процесса поглощения УВ.

5. Разработаны технико-экономические соображения целесообразности внедрения технологии утилизации паров углеводородов.

\section{Список литературы:}

1. Леонов В.Е., Ходаковский В.Ф., Куликова Л.Н. Основы экологии и охрана окружающей среды : монография / под редакцией д.т.н., профессора В.Е. Леонова. Херсон : Издательство Херсонского государственного морского института, 2010. 352 с.

2. Леонов В.Е., Ходаковский А.В. Экология и охрана окружающей среды : учебное пособие / под редакцией д.т.н., профессора В.Е. Леонова. Херсон : Издательство ХГМА, 2016. 348 с.

3. Изменение климата достигло катастрофических масштабов. URL: https://news.rambler.ru/tech/45673808-izmenenie-klimatadostig...25.01.2021

4. Содержание углекислого газа в атмосфере Земли значительно выросло. Деловая газета «Взгляд». 19.09.2019.

5. Hensher D.A., Faqhimnia B. Green logistics and Transportation. Greening of Industry Networks Studies 4. Springer International Publishing Switzerland. 2015. Vol. 65. № 3. P. 131-145.

6. Thalis Zis. H., Angeloudis and Michel G.H. Bell. Economic and Environmental Trade-Offs in Water Transportation. Springer International Publishing Switzerland. 2015. Vol. 65. № 3. P. 159-165.

7. Романов Э.В., Лелецкий А.В., Лабунин К.А. Парниковый эффект: причины, последствия, способы оптимизации. Орел : Вестник Орловского государственного университета имени И.С. Тургенева, 2019. С. 13-18.

8. Антоненко Я.О. Глобальна проблема парникового ефекту: наслідки та шляхи вирішення. Мат-ли IV Miжнар. наук.-практ. конф. 2017. C. 13-15. URL: http://nasoa.edu.ua

9. Абдуллаев С.Ф., Маслов В.А., Абдурасулова Н.А. Изменение концентрации углекислого газа в атмосферном воздухе города Душанбе. Вестник Таджикского технического университета. 2011. № 3. C. 9-15.

10. MEPC 65/INF.17 IMO Model Course on Energy-Efficient Operation of Ships. London : World Maritime University, 2013. $61 \mathrm{p}$.

11. Мелешко В.Л. Изучение возможных изменений климата с помощью моделей общей циркуляции атмосфреры и океана. Изменения климата и их последствия : учебн. пособие. С-Пб. : Наука, 2002. 174 с.

12. Аламанов С.К. Изменение климата и водные проблемы в Центральной Азии : учебн. курс для ст-тов. М.-Бишкек: UNEP, 2006. 188 с.

13. Леонов В.Е., Чернявский В.В. Современные методы исследований и обработки экспериментальных данных : монография / под. ред. д.т.н., профессора В.Е. Леонова. Херсон : ИЦ ХГМА, 2020. 520 с.

14. V. Leonov, A. Gurov. Greenhouse effect. Fiction or result of the prolonged action of the technogenic systems? The Scientific Heritage : Hungary, 2021. Vol. 1. № 60. P. 29-39. DOI: 10.24412/9215-0365-2021-60-1-29-29-39 URL: https://www.elibrary.ru/item.asp?id=44726893

15. Концентрация $\mathrm{CO}_{2}$ в атмосфере вокруг Японии побила рекорд. Российская газета. 30.03.2021.

16. Караваев М.М., Леонов В.Е., Попов И.Г., Шепелев Е.Т. Технология синтетического метанола : монография / под ред. д.т.н., профессора М.М. Караваева. Москва : Химия, 240 с.

17. Леонов В.Є., Гацан О.А., Гацан В.А. Плавучий комплекс для глибоководного видобутку сірководню із морської води і спосіб запуску плавучого комплексу : Патент 92422 Україна, заявл. 25.10.2010; опубл. 23.08.2012, Бюл. № 31 . 


\section{References:}

1. Leonov V.E., Hodakovskiy V.F., Kulikova L.N. (2010) Osnovyi ekologii i ohrana okruzhayuschey sredyi: monografiya / pod redaktsiey d.t.n., professora V.E. Leonova. Herson: Izdatelstvo Hersonskogo gosudarstvennogo morskogo instituta, $352 \mathrm{p}$.

2. Leonov V.E., Hodakovskiy A.V. (2016) Ekologiya i ohrana okruzhayuschey sredyi : uchebnoe posobie / pod redaktsiey d.t.n., professora V.E. Leonova. Kherson: Izdatelstvo HGMA, 348 p.

3. Izmenenie klimata dostiglo katastroficheskih masshtabov. URL: https://news.rambler.ru/tech/45673808izmenenie-klimata dostig...25.01.2021

4. Soderzhanie uglekislogo gaza v atmosfere Zemli znachitelno vyiroslo. Delovaya gazeta «Vzglyad». 19.092019.

5. Hensher D.A., Faqhimnia B. (2015) Green logistics and Transportation. Greening of Industry Networks Studies 4. Springer International Publishing Switzerland, vol. 65, no. 3, pp. 131-145.

6. Thalis Zis.H., Angeloudis and Michel G.H. Bell (2015) Economic and Environmental Trade-Offs in Water Transportation. Springer International Publishing Switzerland, vol. 65, no. 3, pp. 159-165.

7. Romanov E.V., Leletskiy A.V., Labunin K.A. (2019) Parnikovyiy effekt: prichinyi, posledstviya, sposobyi optimizatsii. Orel: Vestnik Orlovskogo gosudarstvennogo universiteta imeni I.S. Turgeneva, pp. 13-18.

8. Antonenko Ya.O. (2017) Globalna problema parnikovogo efektu: naslIdki ta shlyahi virishennya. Mat-li IV MIzhnar. nauk.-prakt. konf., pp. 13-15. URL: http://nasoa.edu.ua

9. Abdullaev S.F., Maslov V.A., Abdurasulova N.A. (2011) Izmenenie kontsentratsii uglekislogo gaza v atmosfernom vozduhe goroda Dushanbe. Vestnik Tadzhikskogo tehnicheskogo universiteta, no. 3, pp. 9-15.

10. MEPC 65/INF.17 IMO Model Course on Energy-Efficient Operation of Ships (2013). London: World Maritime University, $61 \mathrm{p}$.

11. Meleshko V.L. (2002) Izuchenie vozmozhnyih izmeneniy klimata s pomoschyu modeley obschey tsirkulyatsii atmosferyi i okeana. Izmeneniya klimata i ih posledstviya: uchebn.posobie. S-Pb.: Nauka, $174 \mathrm{p}$.

12. Alamanov S.K. (2006) Izmenenie klimata i vodnyie problemyi v Tsentralnoy Azii: uchebn. kurs dlya st-tov. M.-Bishkek: UNEP, 188 p.

13. Leonov V.E., Chernyavskiy V.V. (2020) Sovremennyie metodyi issledovaniy i obrabotki eksperimentalnyih dannyih: monografiya / pod. red. d.t.n., professora V.E. Leonova. Herson: ITs HGMA, 520 p.

14. V. Leonov, A. Gurov. (2021) Greenhouse effect. Fiction or result of the prolonged action of the technogenic systems? The Scientific Heritage: Hungary, vol. 1, no. 60, pp. 29-39. DOI: 10.24412/9215-0365-2021-60-1-29-29-39 URL: https://www.elibrary.ru/item.asp?id=44726893

15. Kontsentratsiya $\mathrm{SO}_{2} \mathrm{v}$ atmosfere vokrug Yaponii pobila rekord. Rossiyskaya gazeta. 30.03.2021.

16. Karavaev M.M., Leonov V.E., Popov I.G., Shepelev E.T. Tehnologiya sinteticheskogo metanola: monografiya / pod red. d.t.n., professora M.M. Karavaeva. Moscow: Himiya, 240 p.

17. Leonov V.E., Gatsan O.A., Gatsan V.A. Plavuchiy kompleks dlya glibokovodnogo vidobutku sirkovodnyu iz morskoyi vodi i sposib zapusku plavuchogo kompleksu: Patent 92422 Ukrayina, zayavl. 25.10.2010; opubl. 23.08.2012, Byul. № 31 . 